\title{
Saccharomycin, a biocide from S. cerevisiae that kill- off other yeasts
}

\section{Jorge Caldeira, Gabriela Almeida, Anjos L. Macedo, José P. M. Silva \& Helena} Albergaria

To cite this article: Jorge Caldeira, Gabriela Almeida, Anjos L. Macedo, José P. M. Silva \& Helena Albergaria (2019) Saccharomycin, a biocide from S. cerevisiae that kill-off other yeasts, Annals of Medicine, 51:sup1, 94-95, DOI: 10.1080/07853890.2018.1562694

To link to this article: https://doi.org/10.1080/07853890.2018.1562694

Published online: 28 May 2019.

Submit your article to this journal $\pi$

Џll Article views: 5

View Crossmark data \lceil 
this study. SC0111 AD1-8 is a strain were all MDR genes are deleted. These genes are responsible to code ABC transporters which in turn play a role in the efflux of xenobiotics. The lower $I_{50}$ value for SC0111 AD1-8 shows that ABC transporters have an important role in the excretion of 4-CMC.

CONTACT Maria Inês Lapo mineslapo@gmail.com
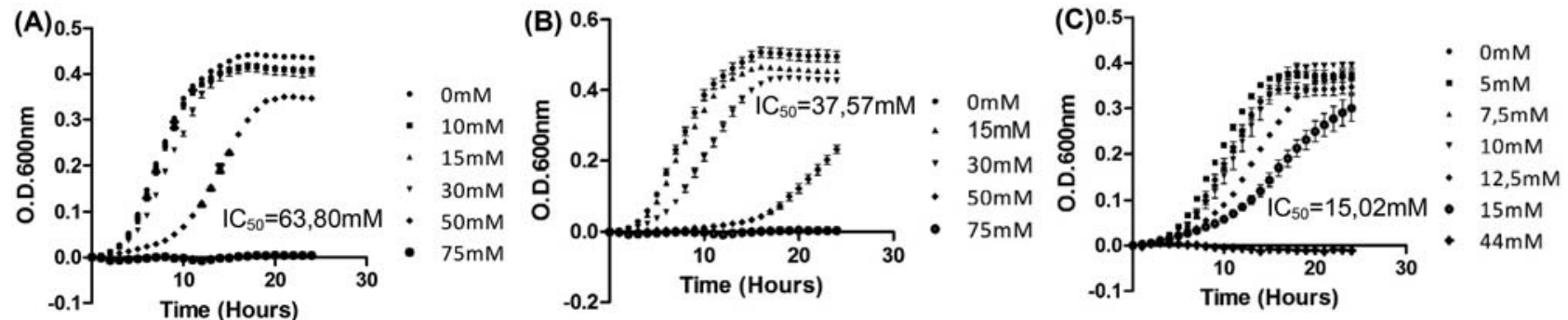

Figure 1. Growing kinetics of S. cerevisiae's cells, for the strains SC006 BY4741WT (A), SC166 BY4741 DPDR5 (B) and SC0111 AD1-8 (C), in the presence of several concentrations of 4-CMC.

\title{
Acknowledgements
}

The authors acknowledge funding from Egas Moniz - Cooperativa de Ensino Superior.

\section{References}

[1] Karila L, Megarbane B, Cottencin O, et al. Synthetic Cathinones: A New Public Health Problem. Curr Neuropharmacol. 2015;13(1):12-20.

[2] Grifell M, Ventura M, Carbón X, et al. Patterns of use and toxicity of new para-halogenated substituted cathinones: 4CMC (clephedrone), 4-CEC (4-chloroethcatinone) and 4-BMC (brephedrone). Hum. Psychopharmacol. 2017;32(3):1-9.

\section{Saccharomycin, a biocide from S. cerevisiae that kill-off other yeasts}

\author{
Jorge Caldeira ${ }^{\mathrm{a}, \mathrm{b}}$, Gabriela Almeida ${ }^{\mathrm{a}, \mathrm{b}}$, Anjos L. Macedo ${ }^{\mathrm{b}}$, José P. M. Silva ${ }^{\mathrm{b}}$ and Helena Albergaria ${ }^{\mathrm{c}}$

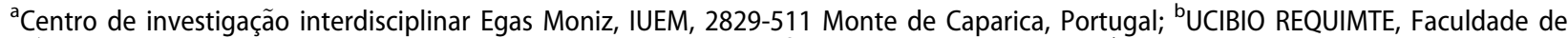 \\ Ciências e Tecnologia (UNL), 2829-516 Monte Caparica, Portugal; ' Unit of Bioenergy, Laboratório Nacional de Energia e Geologia \\ (LNEG), 1649-038 Lisbon, Portugal
}

Introduction: Saccharomyces cerevisiae plays an important role in alcoholic fermentation and is involved in the production of wine, beer and bread. Recent studies [1-7] showed that S. cerevisiae secretes antimicrobial peptides (AMPs), named "saccharomycin", derived from the glycolytic enzyme glyceraldehyde 3-phosphate dehydrogenase (GAPDH) that are active against a variety of wine-related microbial species. AMPs are low molecular weight proteins with broad antimicrobial spectrum of action against bacteria, viruses, and fungi [8]. Organisms use AMPs for defence against infection and membrane interaction appears to be the key to this antimicrobial function: generally they adopt amphiphilic structures that interact with the infectious agent's membrane. AMPs constitute a promising source as alternatives to: i) combat pathogenic bacteria resistant to common antibiotics and ii) substitute chemical preservatives in food-fermented products such as wine. The aim of this study was to discover the mode of action of these peptides by detailed chemical structure characterisation and cell contact mechanism.

Materials and methods: Structural characterization of saccharomycin and of its synthetic analogues was performed by NMR. 2D NMR spectra, COSY, TOCSY, ROESY, and 1H-13C-HMQC (Figure 1) for identifying non-peptide components involved in the chemical structure of saccharomycin by comparison with synthetic analogues. Atomic Force Microscopy (Figure 2) was used to observe the surface of different species of yeast cells upon cell-cell contact. Yeast cells were observed after being collected at different growth stages, either from mixed or pure cultures. Differential proteomic studies were performed to identify S.cerevisiae metabolic pathways involved in the production of AMPs using 2D electrophoresis coupled to MS techniques 